\title{
THE PATHOGEN TRANSMISSION AVOIDANCE THEORY \\ OF SEXUAL SELECTION
}

\author{
2FCEIVED \\ Allo 121997 \\ OSTI \\ Craig Loehle \\ Environmental Research Division \\ Argonne National Laboratory \\ 9700 S. Cass Avenue \\ Argonne, IL 60439
}

\begin{abstract}
The current theory that sexual selection results from female preference for males with good genes suffers from several problems. An alternative explanation, the pathogen transmission avoidance hypothesis, argues that the primary function of showy traits is to provide a reliable signal of current disease status, so that sick individuals can be avoided during mating. This study shows that a significant risk of pathogen transmission occurs during mating and that showy traits are reliable indicators of current disease status. The origin of female choosiness is argued to lie in a general tendency to avoid sick individuals, even in the absence of showy traits, which originate as exaggerations of normal traits that are indicative of good health (bright feathers, vigorous movement, large size). Thus, in this new model the origins of both showy traits and female choosiness are not problematic and there is no threshold effect. This model predicts that when the possession of male showy traits does not help to reduce disease in the female, showy traits are unlikely to occur. This case corresponds to thorough exposure of every animal to all group pathogens, on average, in large groups. Such species are shown with a large data set on birds to be less likely to exhibit showy traits. The good-genes model does not make this prediction. The pathogen transmission avoidance model can also lead to the evolution of showy traits even when selection is not effective against a given pathogen (e.g., when there is no heritable variation for resistance), but can result in selection for resistance if such genes are present. Monogamy is argued to reduce selection pressures for showy traits; data show monogamous species to be both less parasitized and less showy. In the context of reduction of pathogen transmission rates in showy populations, selection pressure becomes inversely frequency-dependent, which makes showy traits likely to be self-limiting rather than runaway. Overall, the pathogen transmission avoidance hypothesis provides a complete alternative to the goodgenes theory and makes new predictions.
\end{abstract}

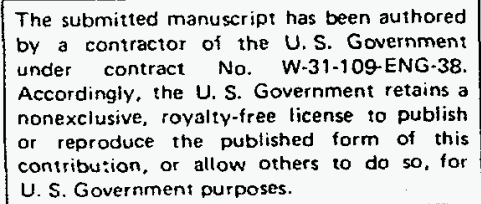




\section{INTRODUCTION}

One of the great conundrums in evolutionary theory is the origin and maintenance of secondary sex traits. That these traits do not contribute directly to survival and may even increase mortality was clear to Darwin and caused him to propose the theory of sexual selection, later elaborated by Fisher (1958). The Fisher process has seemed rather difficult to accept because there is no net benefit to the traits and extinction can even result. The alternative good genes models require certain restrictive assumptions concerning linkage disequilibria and there are problems initiating the process, though Grafen $(1990 \mathrm{a}, \mathrm{b})$ has shown that indirect selection via a handicap process (Zahavi, 1975; 1987) can work. Several authors (Freeland, 1976; Borgia and Collis, 1989, 1990; Clayton, 1990, 1991; Hamilton, 1990; Kirkpatrick and Ryan, 1991; Loehle, 1995) have proposed that whereas secondary sex traits are not necessarily reliable indicators of fitness, they are reliable indicators of current disease status. A female using these traits to avoid contamination during mating or during nest-keeping (or both) will obtain an advantage in fitness. Price et al. (1993) developed a general model of sexual selection in which females showing a preference for showy males receive a direct benefit when showy traits reflect condition. This model led to classic sexual selection outcomes without assuming any linkage disequilibrium or heritability of male quality (fitness). Direct benefits could include control of resources (e.g., a territory), male defense, male provisioning ability, and reduced pathogen transmission.

The case of pathogen transmission fits the direct selection model of Price et al. (1993), which I take as a jumping off point. I do not assume here that avoidance of pathogen transmission is the sole driver behind sexual selection. Rather, I ask what would we observe if it were dominant. I thus seek to expand the arguments of Price et al. (1993) for the particular direct selection case of a benefit solely via avoidance of pathogen transmission, in the following areas: 1) The origin of female preference, currently treated as arbitrary, is given a biological foundation; 2) A pathogen transmission process implies frequency dependence. Epidemic models and explicit 


\section{DISCLAMIER}

Portions of this document may be illegible in electronic image produets. Images are produced from the best available original document. 
population dynamics are shown to be necessary to answer questions about net changes in fecundity and selection strength; 3) Criteria are proposed for testing between the different models; and 4) An explicit test is performed of certain predictions related to group size effects.

Before considering alternate theories, it is important to distinguish two types of secondary traits. Contest-related traits are used directly in male contests for females but are not necessarily involved in female choice. In wild horses the males fight over and control harems. In elephant seals, size determines the outcome of fights for territory. Females do not appear to actively choose in these cases. I thus exclude such secondary traits from this discussion, because they may be simply explained as an outcome of contest competition. In contrast, showy traits include singing displays, bright feathers or other markings, long tail feathers or crests, wattles, dances, bowers, and offers of food. These showy traits are influential in systems in which females can choose a mate or reject a suitor. The antlers of deer may result from a mix of contest and showy selection pressures.

A popular model for sexual selection is the good-genes model (Grafen, 1990a,b; Andersson, 1994; Hamilton, 1990; Hasson, 1989; Hill, 1990, 1991, Lande, 1981; Pomiankowski, 1988; Zahavi, 1975, 1987). The parasite resistance version of the good-genes model (Hamilton and Zuk, 1982) is based on the following propositions: (1) parasites affect the quality or appearance of male displays, (2) females can respond to these condition-dependent displays, (3) male resistance to parasites is heritable, and (4) females obtain better genes for their offspring by choosing showier males for mating. Other versions of good-genes models can be formulated in which the viability trait is not necessarily related to parasite resistance. I here focus mainly on the parasite resistance version, but refer also to more general viability models.

The good-genes theory has several problems. In general, as an indirect-selection model, this theory depends on a weaker evolutionary process than do direct-selection models. The first in a series of particular problems is that secondary sex traits do not provide a reliable indicator of 
fitness or even of the possession of genes for pathogen resistance (Kirkpatrick, 1986, 1989; Loehle, 1995; Read, 1988).

Second, in the good-genes theory one must make rather strong, arbitrary assumptions about genetic linkages between genes for female preference and secondary sex traits to initiate the selection process (Andersson, 1994; Lande, 1981; Pomiankowski, 1988); this is the linkage threshold effect. Although such genetic linkages have been shown to occur in showy species (Bakker, 1993; Houde and Endler, 1990), their origin is problematic.

Third, in the good-genes model females must happen to have a preference for a particular unusual, showy trait when this trait first occurs, and when both the showy trait and the female preference are rare, the choosy female and the showy male must happen to encounter each other. These multiple infrequent circumstances create a frequency threshold effect; a minimum frequency of both showy males and choosy females is required to initiate selection, or both traits will be extinguished by genetic drift and opposing selection forces (due to costs of showiness and choosiness, respectively). Fourth, because most species suffer adversely and often catastrophically from parasites and disease, under the good-genes model more species might be expected to exhibit bright coloration or other displays. Actually, trends in species without showy traits are consistent with a pathogen transmission avoidance explanation (see below). Fifth, why females should exhibit any preference for an initially rare and unusual trait is problematic. In contrast, the pathogen transmission avoidance model posits that only initially rare novel traits that act as amplifiers of signs of health will be favored, but the favoring of incipient amplifiers is not problematic.

Runaway sexual selection, posited by Darwin and formalized by Fisher (1958), is another indirect-selection process with all the problems of the good-genes theory, including the linkage and frequency threshold effects for initiating selection. In particular, Nichols and Butlin (1989) argued 
that a purely runaway process cannot maintain linkages between alleles affecting the sexual character and alleles affecting preference. Fisher (1958) maintained that the initial advantage of the trait preferred by females is direct, as with longer tail feathers, and that this initial direct advantage of female preference allows the preference trait to become sufficiently strong to initiate the runaway process. If an initial direct benefit can be identified, then we can invoke a direct selection process as in Price et al. (1993) and need not resort to runaway selection. A more serious problem is that runaway sexual selection provides no fitness benefit vis-a-vis competing species and can even lead to extinction, because energy is expended on the traits, and the predation risk increases. As demonstrated below, numerous other difficulties with this model make it even more implausible. Further, as Kirkpatrick and Ryan (1991) noted, obtaining positive evidence for runaway selection would be very difficult.

\section{THE PATHOGEN TRANSMISSION AVOIDANCE HYPOTHESIS}

Under the hypothesis that sexual selection acts to reduce pathogen transmission, secondary sex traits are hypothesized to be reliable flags or markers by which the female (usually) can determine which individuals are diseased so that she can avoid them. This is a direct-selection model, because the benefit of female preference accrues directly to the female in terms of her fecundity rather than indirectly in terms of fitness of her offspring. As Kirkpatrick and Ryan (1991) noted, direct selection is much more efficacious and is more likely to optimize the female's fitness than is indirect selection (such as the good-genes model) and does not require genetic correlation for the exaggeration of either the male trait or the female preference.

Perhaps the earliest mention of the pathogen transmission avoidance hypothesis was by Freeland (1976), predating even the parasite-mediated model of Hamilton and Zuk (1982). A number of other authors have mentioned this hypothesis (Borgia and Collis, 1989, 1990; Clayton, 1990, 1991; Hamilton, 1990; Kirkpatrick and Ryan, 1991; Loehle, 1995; Price et al., 1993); however, the full implications of pathogen transmission avoidance have not been explored until 
now. For example, Borgia and Collis (1990) elaborated some predictions of the model, but they focused on parasites rather than more broadly on pathogens, did not deal with population genetics issues, and developed only a few specific predictions of the theory. Price et al. (1993) developed a general direct selection model in which reduced pathogen transmission is one possible benefit. A more complete treatment of theory assumptions and predictions is developed here, including a more extensive comparison with published data.

Several conditions must be met for the pathogen transmission avoidance theory to hold: (1) A significant risk of pathogen transmission must occur during mating; (2) Secondary sex traits must be reliable indicators of current disease status; (3) The fact that females are usually choosier than males must be explained; (4) The types of species exhibiting showy traits must be explained; and (5) Selection models must be consistent with the hypothesis. I explore each of these five conditions in turn.

Although disease transmission, especially during mating, has not been studied extensively, enough data exist to posit a significant risk to most animals. Mating is a route for transmission of STDs (e.g., simian SIV), other diseases, skin parasites, and yeast and fungal infections, both to the partner and to the offspring (Service, 1986). Brucellosis (Witter, 1981) and myxomatosis (Yuill, 1981) may be transmitted by mating and may kill directly or cause sterility. Rabies may be transmitted by biting during mating encounters. In rats, prevention of male grooming after copulation leads to a high incidence of transmission of genital infections (Hart and Haugen, 1971; Hart et al., 1987). Hart (1990) argued that postcopulatory autogrooming in the genital area evolved for prevention of disease and noted that species exhibiting such behavior have fewer STDs than species that do not. Another example of possible autogrooming occurs in satin bowerbirds, in which the females but not the males shake violently after copulation in an apparent attempt to dislodge ectoparasites (Borgia and Collis, 1990). As noted below, this difference is to be expected, because females are at greater risk from pathogens while gravid and rearing young and 
further may transmit a new parasite or disease to the young, where it may cause more serious illness, whereas male satin bowerbirds do not contact the young. Clayton (1991) summarized studies showing ectoparasite transmission during mating in guppy, stickleback, sage grouse, pheasant, rock dove, barn swallow, grackle, zebra finch, and bower bird. Clayton (1990) showed that ectoparasites can transmit viruses, bacteria, heartworm, and cestode and filarial nematodes, among others. In birds, ritual feeding as a part of courtship allows stomach contents from the male to pass directly to the female, potentially carrying both diseases and gut parasites. Thus, mating clearly poses a significant risk that deserves more thorough study.

The second condition is that secondary sex traits must provide a reliable indicator of current disease status. Displays and mating dances are clearly affected by the health of the male (e.g., in parasitized guppies [Kennedy et al., 1987]). Physical signals have also been shown to be affected by health. Rätti et al. (1993) showed that pied flycatchers infected with Trypanosoma had shorter tails and shorter wings and arrived at the breeding grounds on average two days later than uninfected individuals, with a consequent reduction in breeding success. Bower provisioning is affected by an individual's vigor. Illness can affect the luster of the fur in dogs. Other effects were documented by Barnard (1991), Catchpole (1987), Hill (1990, 1991), Hoelzer (1989), Lyon and Montgomerie (1986), Mфller (1991), Searcy and Andersson (1986), and Simmons (1988), and summarized by Hill (1995), Clayton (1991), Price et al. (1993), and Andersson (1994). Overall, Price et al. (1993) argue that virtually all traits on which females exhibit preference can be shown to be condition dependent. The scant data available suggest that females will avoid diseased males even in the absence of secondary sex trait "flags" (e.g., Edwards and Barnard, 1987; Kennedy et al., 1987). Edwards (1988) found that healthy mice direct increased exploratory behaviors (e.g., sniffing) toward infected mice but exhibit less contact. Loehle (1995) and Hart (1987) documented other avoidance behaviors. 
These observations support the concept that infections (particularly if severe) affect secondary sex traits. Further, the observations suggest a mechanism by which sexual selection may begin. If a general tendency exists to avoid ill individuals, as Loehle (1995) documented, and if these individuals can be avoided to some extent during mating even in the absence of secondary sex traits, then the basic female behavior of avoidance is preexistent. This set of preexistent behaviors would overcome the difficulty in the good-genes and runaway-selection models of explaining why the female would exhibit an initial preference to get the selection process started. Such avoidance behavior would also solve a second difficulty of explaining why particular traits are preferred. Almost all secondary sex traits (especially when incipient) appear to represent an exaggeration of traits exhibited by healthy individuals: vigorous movements, bright colors, loud singing, etc. This assertion seems to me self-evident in the majority of cases, but quantifying and testing whether particular traits represent exaggerations of signs of health will not necessarily be easy. Females thus exhibit a natural preference for such traits because they amplify the signal of healthiness. This model further explains the arbitrariness of the traits: any random exaggeration of normal signs of health and vigor will provide a reliable signal of disease status and can be amplified by being favored. In contrast, in the good-genes and runaway-selection models, any condition dependent trait or any distinct trait, respectively, will suffice. Thus, the fact that most secondary sexual traits are exaggerations of signs of vigor can be explained by the pathogen transmission avoidance model but not by the other two models. We may further note that multiple showy traits can arise in the same species (e.g., crests and long tails) if female preference is based on general amplifiers of signs of health. In contrast, other models seem to require a specific preference trait in the female to match the particular male showiness trait and fail to explain the occurrence of multiple showy traits.

The third condition is that we must explain why females are choosier than males in general. The standard explanation is that females invest more energy in a smaller number of young, an observation that is certainly true. The implication is that females should be more picky than males 
about the gene quality of their partners; however, females also are at more physiologic risk from disease than are males. Because female reproductive structures are internal in mammals, females are more affected by certain diseases than are males (e.g., yeast and chlamydia infections in humans). Autogrooming after mating is less effective in female mammals for the same reason. In birds, diseases passed by ritual feeding during courtship will travel exclusively toward the female, increasing her risk. Likewise, in birds body fluids are passed unidirectionally during copulation toward the female, since most male birds do not penetrate the female with an organ. Although males often become exhausted during the breeding season, females face a longer period of stress while gravid and while raising young. Sickness during this period poses a substantial risk. In addition, the female might pass a disease or parasite on to the young, which will suffer inordinately as newborns. For these reasons, we would expect females to be far more averse to risk of disease than males. When males perform the sole nest-keeping role, as in phalaropes, their stress and risk of passing disease to the young may exceed the female's, and male-female showiness roles may be reversed (as in phalaropes).

Fourth, we must explain the types of species that are likely to exhibit showy traits. Because most species are likely to be at some risk from disease and parasites, the fact that only certain species exhibit showy traits is an anomaly. The pathogen transmission avoidance model provides an explanation. If choosiness is to be beneficial, the selection of a disease-free mate must reduce the risk of disease. If, however, the animal typically lives in very large social groups, then each animal is largely exposed to all of the pathogens of the entire group (see Freeland, 1976), negating the benefit of extra choosiness. This should be particularly true for species that nest colonially because such colonies not only accumulate waste products but become infested by ectoparasites. In such species showy traits provide little benefit to the choosy sex, and provide a strong negative selection via differential predation. Flocking birds that nest alone should be more likely to exhibit secondary sex traits but less likely than solitary species. Note that some species are brightly colored and live in large flocks, but males and females do not differ. Bright coloration 
in these birds serves some other purpose, such as species recognition. Thus the pathogen transmission avoidance model specifically predicts that showy secondary sex traits will be largely confined to species in which mating and nest-keeping are primary modes of pathogen transmission, which is not the case for species living in large groups. There should be extreme selection against dimorphism in colonial nesting species (tested below).

The final condition is the existence of a selection model consistent with the pathogen transmission avoidance theory. The mechanism postulated here to be operative is a condition indicator mechanism sensu Price et al. (1993). Their model is based on the assumption that the female does not necessarily prefer the trait in question per se, but rather that the trait amplifies the ability of the female to make some other discrimination. That is, the mechanism of selection is based on condition indicators, not on quality indicators. A key distinction is that condition need not be heritable but can vary with male age or current health. While these are not necessarily mutually exclusive, one can have differences in disease status even in a population lacking variation in disease resistance. Evolution for disease resistance will not always be possible if, for example, the disease mutates on a regular basis (e.g., flu and HIV in humans). Price et al.'s model of amplifier traits as indicators for male condition shows that the male showy trait can invade and go to fixation. Under the pathogen transmission avoidance model, the same basic process allows the male trait to be selected, but the model is modified such that poor-condition males can produce poor offspring (because they are infected) and can also carry a direct risk to the female via increased pathogen transmission. Other types of direct benefits are not considered. This makes it a direct selection rather than indirect selection model. A major modification to the Price et al. (1993) direct selection model involves the population-level consequences of extent of showiness/choosiness on epidemic risk and hence on selection pressure.

To incorporate risk of pathogen transmission in a simple illustrative model, I model the selection process as a contest between choosy $(C)$ and nonchoosy $(N C)$ types of females. A 
specifically epidemic model-based approach is taken. Steady-state near-equilibrium is assumed, and the total population $(T=N C+C$ ) is regulated near $K$, (the steady-state level) with growth rate $r$. The nominal death rate $D=0.2$ assumes a five-year life span per animal (so that all individuals in a cohort die by the end of year five). Choosiness has no cost, because the female is assumed to be approached by multiple males over time, each being accepted or rebuffed. That is, choosiness entails no risk of failing to mate, and no energy is spent searching for the perfect mate. Relaxing this assumption (see Grafen, 1990a,b) is sufficient to extinguish choosiness if it provides no benefit. Males are of two types: showy (S) and not showy (NS). Showy males have a slightly increased risk of predation (2\%/yr higher). Males of each type can be either infected or healthy, but there is no heritable pathogen resistance trait. The pathogen is assumed to be a sexually transmitted, incurable disease that increases mortality from 0.2 to 0.3 per year and decreases reproduction to zero if either the male or female has it at mating time. Non-infected matings produce up to 2 male and 2 female healthy offspring whose showiness and choosiness type matches that of their parents. Non-choosy females mate at random with all four male types in proportion to their abundance. Choosy females mate only with healthy showy males. The simulation was run at an annual time step for a prolonged period.

The results of the model are very interesting (Figure 1). When choosy females are present, the non-showy males are driven from the population and simultaneously the pathogen is eliminated. As the pathogen is eliminated, selection against non-choosy females decreases and then ceases, and they remain as a subordinate genotype. Thus the benefit to choosiness, assumed constant in other models, becomes a decreasing frequency-dependent function of the occurrence of the choosy female type when an epidemic model is included. This makes the sexual selection process less likely to be runaway and more likely to be self-limiting under this process. Examination of North American birds (Robbins et al., 1983) shows that extreme dimorphism is extremely rare. Complete elimination of the pathogen only occurs when showy traits provide perfect information on disease status, which is rarely the case. 
A second simulation started with equal numbers of showy and non-showy males, but made all females non-choosy, with all else as before. Because of the predation cost of showiness, this trait was gradually eliminated. In this case, the percentage of the population diseased settled down to $57 \%$ (typical values for parasitism range from 0.4 to 0.85 [Gibson, 1990; Pruett-Jones et al., 1990]). With the increased turnover from disease, the total steady state population was lower ( 25775 versus 26850 or $4 \%$ lower) for the case with non-choosy females. This shows that the net fecundity effect of the showy traits is positive. Since larger populations are at lower risk of extinction, this means that fitness at the population level (in terms of persistence) has also been increased, whereas a runaway model per se can lead to lower populations due to increased predation on showy males. This model even gives a female: male sex ratio of 1.08 in the choosy population. No founder effect is needed to initiate the displacement of the nonchoosy females, and the choosy females can invade even when they are rare. Figure 2 summarizes the effect of male traits and female choosiness on epidemic (disease) risk, and the consequent frequency-dependence of the selection process.

Another way to look at the selection of showy traits is in terms of the direction and rate of selection. In Figure 3, the arrows represent the selection vector in the pathogen transmission avoidance model, with the length of the arrow representing selection strength. At lower left, I hypothesize a preexistent female choosiness, based on pathogen avoidance. The initial rate of selection is slow, because the male trait is incipient and does not provide much information on disease status. As female preference and male showiness increase, the strength of selection (and the rate of change) increase (see Figure 2). As the male becomes quite showy, the rate of selection diminishes for at least three reasons. First, as showier males become less fit (due to increased predation risk, etc.), the female's sons become less fit if she chooses a male that is too showy. Second, if showy traits help reduce pathogen transmission rates, then as showiness and choosiness increase, the disease risk decreases and the selection pressure favoring female choosiness will therefore decrease. Third, male showiness is likely to have diminishing returns 
from the female's perspective. In a good-genes or runaway selection model, the showiest individuals always have an advantage in mating. In a pathogen transmission avoidance model, it is sufficient for the female to be able to discriminate between two classes: sick and healthy. At the degree of showiness at which the female is largely successful in making this distinction, selection pressure will cease to increase the degree of choosiness or the extremity of the traits preferred. I believe that this concept explains why so many species exhibit only a modest degree of showiness and only a minority of species are extremely showy. In contrast, runaway selection should more often produce extreme traits once the process is initiated. Some limited data support this prediction of the pathogen transmission avoidance model. Houde (1987) showed that in guppies, mating success for males increased with the percentage of orange coloration, but only up to a threshold beyond which females did not exhibit a higher preference. This is exactly the response predicted by the pathogen transmission avoidance model for a trait used only to discriminate sick versus healthy individuals.

To summarize, the pathogen transmission avoidance model predicts that showy traits should originate as exaggerations of features indicative of health and vigor, that showy traits should be reliable indicators of current health but not necessarily of the possession of good genes, and that species living in large social groups should not generally benefit from showy traits. The model explains the advantages of fitness that choosy females gain, and it further predicts a fitness advantage for the population due to reduced mortality. Choosiness will increase a female's fitness even in the absence of heritable variation for pathogen resistance (which occurs when a population is faced with a novel pathogen); that is, sexual selection in this model need not result in selection for good genes, although it will do so if such genes are present. Finally, selective pressures for showiness should be reduced in monogamous species. 


\section{PREDICTIONS AND TESTS}

Before the predictions and assumptions of the three models are compared, a caution on the interpretation of heritability studies is in order. Such studies examine the fitness of the offspring of females that have mated with males displaying various degrees of showiness. The correlation between male showiness and the survival and/or vigor of offspring is taken as an indicator of the linkage between showy traits and good genes in the male. However, the showiness of the males could result from freedom from pathogens that is unrelated to male fitness (e.g., due to chance lack of exposure). The lack of pathogens would be translated into reduced transmission to the female and her offspring, which would lead to the expected (but possibly spurious) correlation. Thus, data that appear to support the good-genes model might actually support the pathogen transmission avoidance model.

In such studies it is difficult to control for transmission of pathogens. It is not sufficient to say that the organism under study (say a particular ectoparasite) was not transmitted to the female or even that it was nontransmissible, because other pathogens, including yeasts, fungi, bacteria, and viruses, could have been transmitted. Since condition-dependent ornaments are affected by overall vigor, we would expect the risk of transmission of all of these pathogens to be reduced in the brighter males which are overall in better health, thus potentially confounding heritability studies for male quality (good genes). In a heritability study, a demonstration that no significant pathogen transmission has occurred is required for the results to be supportive of the good-genes theory. In the absence of this proof, heritability studies will equally well support the pathogen transmission avoidance model. Again, it is not sufficient to show that the female did not become overtly sick following mating, because a mild infection of the female can reduce egg or fetal quality or be transmitted to the newborns. For example, in humans a yeast infection in the birth canal can be transmitted to the newborn as thrush, which can be very serious. Ectoparasite infections in 
birds have been shown to be transmitted to the young, in which such infestations are much more serious than in adults.

The power of a theory is demonstrated by both its predictive and explanatory capabilities. The good-genes and runaway-selection models leave a number of things unexplained (Table 1), such as why females are initially choosy (to get the selection process started) and why certain traits become subject to selection. The pathogen transmission avoidance model provides explanations for initial female preference and the types of male traits selected, and also makes certain new predictions, such as the absence of showy male traits in species that live in large groups and decreased showiness in monogamous species. The predictions or experimental tests below allow a comparison of the three models.

1. Group size effects. In the pathogen transmission avoidance model, sexual selection is less likely to occur if mating choosiness does not reduce the rate of pathogen transmission. This situation exists in large social groups, where the individual is thoroughly exposed to most group pathogens. Showy traits should be less common in such species and should be very rare in species that nest colonially. A comparative approach is necessary to test this prediction. The bird fauna of North America was chosen for analysis because it is thoroughly characterized and is familiar. An operational definition of showiness chosen was sexual dimorphism. What is of interest here is showy traits within a species that could be indicators of current disease status. In particular, traits that are exaggerations of normal species traits are of interest because they provide a contrast. Thus it is not absolute brightness but degree of difference or exaggeration that provides the classification. Flamingos are bright in an absolute sense, but males and females are identical. The model proposed here requires exaggeration of some trait, but simple brightness is merely part of the species identification gestalt and is not sufficient as an indicator. For sexual dimorphism, Robbins at al. (1983) was consulted. Degree of dimorphism was not evaluated, just 
presence/absence. Dimorphism was in most cases obvious. Raptors were classified as dimorphic based on size dimorphism.

Social behavior was assessed based on Robbins et al. (1983) and Terres (1980). Only common breeders in North America were included. Three classes were identified: colonial nesters, gregarious species, and solitary species. Colonial nesting is a particularly risky lifestyle with respect to pathogens because of the buildup of excreta and the increased occurrence of ectoparasites. Non-dimorphic colonial nesting birds include the pelicans, tubenoses, herons, storks, ibises, spoonbills, flamingos, cranes, jaegers, skuas, gulls, terns, alcids, swifts, and swallows. The dimorphic colonial nesters were the frigate bird, anhinga, one swallow, and four eider ducks. Species were classified as gregarious if they forage on the ground in medium to large groups. In this setting, pathogen exchange is likely. Birds catching insects in the air in groups would not fall into this category, but most such species (example, swifts) are colonial nesters. Among the song birds there was some ambiguity as to whether they were solitary or gregarious. These species almost all nest alone but may forage in small to medium size flocks. Interestingly, this group showed the most variation in dimorphism within sets of related species (see appendix). Out of 656 species, social behavior of 11 could not be determined. These species were dropped.

A contingency table $\left(\chi^{2}\right)$ analysis was conducted of the remaining 645 species (Table 2). This table shows the extremely unbalanced distribution of colonial nesting species, which are overwhelmingly not dimorphic ( 7 dimorphic versus 137 not). Gregarious species are more mixed (76 dimorphic versus 124 not) but are still largely not dimorphic, as predicted. It is among solitary species that dimorphism becomes dominant (199 versus 102 or $2: 1$ ), again as predicted. The overall $\chi^{2}$ test is highly significant $\left(\chi^{2}=131.2\right.$ versus $\left.\chi_{.99}^{2}(2)=10.6\right)$, indicating that this trend is real. Figure 4 gives a clear picture of the trends. Given that pathogen transmission is only one of the costs of living in groups, it is not surprising that there is considerable variation within the gregarious category, which is also partly due to varying group sizes within this category. Thus the prediction of the pathogen transmission model is strongly supported, particularly by the fact that $95 \%$ of the colonial nesting species are not dimorphic. 
It is necessary to contrast the results above with that predicted by other models. The good genes model argues that when species suffer excessively from parasites (or pathogens in general) then there should be stronger selection pressure for showy traits as indicators of good genes for disease resistance. This situation pertains particularly strongly in the case of species that nest colonially. Excreta in bird colonies can be excessive, ectoparasites are common, and bird-to-bird contact rates are high, facilitating disease spread. Colonial nesting species and species in large flocks are known to suffer periodic epidemics and die-offs. Thus it would seem by the good genes model that colonial nesting species should have the highest rates of showy traits, exactly the opposite of what was found here. In contrast, the sexy son hypothesis seems to require a random origin for showy traits with respect to group size and taxa. Not only is dimorphism in birds not random with respect to group size (Table 2), but there is a definite consistency within groups of related species (genera or higher) (see Appendix). Thus, although past studies have not addressed group size effects, the logical extension of the good genes and sexy son models to this question lead to predicted patterns at odds with those found for birds, at least.

2. Efficacy of females in avoiding sick males. Sick individuals should be more effectively selected against during mating in a showy species than in a dull species if showy traits act as amplifiers. In a test of this prediction, Pruett-Jones et al. (1990) concluded that in birds of paradise, females actively avoided highly parasitized males. Other authors have also shown a much higher mating success for the most disease-free males (Borgia and Collis, 1989, 1990) even in cases where sexual dimorphism is minimal (e.g., Clayton, 1990). Interestingly, cases exist in which the male coloration and display both give the female the opportunity to directly observe parasite load, as in the dark feathers and head display in the satin bowerbird (Borgia and Collis, 1990). In this species, the male's dark head amplifies the ability of the female to detect parasites. Such cases are much more parsimoniously attributed to female avoidance of pathogens than to preference for a showy trait per se. Evidence that breeding males groom more in a possible attempt to reduce their parasite load (Borgia and Collis, 1990) would only make sense if females were 
judging parasite load per se rather than good genes. Definitive data on this issue would come from a comparison between showy and nonshowy species in the extent to which females can avoid highly parasitized or very sick males. Such data do not currently exist.

3. Heritability of resistance. Although increased fitness of offspring sired by showy males is predicted (as in von Schantz et al., 1994), cases are also predicted in which heritability of fitness cannot be demonstrated to be linked to showy traits, in contrast to the good-genes hypothesis. [Note again the difficulty of separating heritability of fitness from lack of pathogen tranmission.] These latter cases should occur where pathogen transmission avoidance increases female fitness without heritable variation in pathogen resistance. Such lack of heritability of fitness can occur either with a novel pathogen or with one for which resistance has evolved as far as possible. Another possible outcome is that heritability of a trait is high but does not increase in the population because of tradeoffs with other traits. Thus, heritability alone does not prove selection by a goodgenes model. The pathogen transmission avoidance model does not deny that linkage between showiness and pathogen resistance is possible, but it denies that such linkage is necessary for sexual selection and thus predicts that the results of heritability studies will be ambiguous, a prediction borne out in current correlational studies of wild populations (Clayton, 1991). The pathogen transmission avoidance model particularly allows sexual selection to become initiated without heritable resistance, which may enter the picture at a later time.

4. Showiness and disease resistance. Showy individuals may exhibit increased disease resistance, but there should be cases where they do not (for the same reasons as in point 3 , again in contrast to the good-genes hypothesis, which posits a strong link, although the runaway-selection model posits no link). Few tests have been performed on the actual pathogen resistance of showy males, even though this would seem to be a central prediction of the parasite resistance theory. With condition-dependent ornaments, the fact that the showier males are less parasitized does not prove a genetic basis for resistance. Indirect evidence for the lack of increased disease resistance 
of showier males is an extreme variability in blood parasite intensity for males remeasured over different dates, as shown by Pruett-Jones et al. (1990) for Parotia lawesii, and by the fact that some males were successful at mating when their parasite load was low but failed when their load was high (though sample sizes were small). Gibson (1990) showed a strong effect of year for infection levels in sage grouse but did not report repeat measures for the same birds separately. Borgia and Collis $(1989,1990)$ showed that more than $50 \%$ of the uninfected satin bowerbirds one year would be infected the next, with a similar number going from infected to uninfected. Although they showed a weak correlation over time in infection levels for the same birds, individual birds clearly were not so consistently infection-free that any particular showy phenotype could be considered a reliable indicator of good genes. More data of this type are needed.

5. Species brightness and parasite load. If the main contribution to fitness is from reduced pathogen transmission and not from genetic factors (i.e., if biological resistance is ineffective), then species with the highest parasite loads should have the brightest feathers (or other markings), as has been observed in jungle fowl (Hamilton and Zuk, 1982). I believe that the good-genes theory should make the opposite prediction if good genes are linked to showy traits. That is, this theory should predict that the showiest species will be the healthiest.

Let us consider this question as an evolutionary process according to a good-genes model. Two species, A and B, have a certain parasite load L. Species A gradually evolves resistance, while the parasites coevolve at approximately the same rate. In species B, a process of sexual selection begins, allowing females to more effectively choose males with parasite resistance genes. In $B$, the rate of selection for resistance should be faster than in $A$, because females can (in theory) choose to mate only with more resistant males. Thus choosiness should lead over time to a reduction in infection or mortality rates. If $\mathrm{A}$ and $\mathrm{B}$ are types within a population, we assume that the reduction in mortality in B due to resistance genes is what causes the showy type to drive out the nonshowy type. This argument seems to imply that the result of sexual selection should be reduced parasitism compared to that in related species without showy traits. The exact opposite of 
this was predicted by Hamilton and Zuk (1982), perhaps because proximate and ultimate evolutionary pressures were being confounded. Species with higher initial parasite loads may be under stronger initial selective pressure, but the ultimate result of the sexual selection process under a good-genes hypothesis should be increased resistance compared to related species. To rescue the observed correlation, the cycling parasites hypothesis has been invoked to maintain selective pressure for the showy traits. While models of cycling parasites have been shown to work, direct evidence for this phenomenon has been difficult to obtain. The fact that the showiest species have the highest parasite loads (Clayton, 1990) seems to be an indictment of good-genes models. Interestingly, a runaway-selection model can predict that the brightest species are the most parasitized if the show has a significant energetic cost, thereby causing the animal stress. Mating displays are in fact known to be energetically costly.

The pathogen transmission avoidance model also predicts that the brightest species may be the most parasitized. If the pathogens that dominate mortality are not readily subject to physiological control, then transmission avoidance can become more advantageous than evolutionary adaptation. Directly transmissible viruses and bacteria, for example, often exhibit epidemic behavior and cause high mortality. If a species is susceptible to pathogens that are lethal or debilitating and the pathogens are transmissible and not readily controlled by physiologic adaptation (the case in most sexual selection studies to date), then avoidance becomes advantageous. In such a case, the sexual selection process will not necessarily lead to increased resistance but rather to more effective avoidance behaviors. The pathogen transmission avoidance model predicts that offspring mortality should be reduced compared to that in related nonshowy species because of reduced transmission via the female. Offspring survival has rarely been quantified across related species, but it is a key prediction of the pathogen transmission avoidance model. Heritability studies in which offspring sired by showy males have higher survival rates might in fact provide strong support for the pathogen transmission avoidance model if the genetic versus pathogen transmission components of offspring survival could be distinguished. Perhaps only artificial insemination could allow these effects to be untangled. 
To date, interspecies comparisons of pathogen load versus brightness are certainly variable in their outcome (Clayton, 1990; Kirkpatrick and Ryan, 1991). Whether this variability is real or reflects experimental difficulties (e.g., Read and Harvey, 1989) is not clear. Comparisons of parasite loads between species will obviously be fraught with difficulties. Some parasites exist at high densities but are relatively benign. Others, even at low densities, can be serious (e.g., sterility caused by chlamydia). Still others are highly episodic in their effects. A convincing case has not yet been made for a metric for comparing parasite loads (including disease) across species and taxa. Subjective estimates of degree of brightness or showiness are similarly perilous when species differ in the traits to which they respond (i.e., females are not responding to a human "brightness" score). Certain aspects of coloration, such as feather irridesence, may not even be visible to humans.

6. Origin of traits. The pathogen transmission avoidance theory postulates that showy traits should have originated as exaggerations of normal traits that are indicative of good health, but that the particular traits that occur may be variable. This mode of origination would explain the huge diversity of secondary sex traits (tail feathers, wattles, crests) and behaviors (calls, dances, creation of bowers) and their divergence within taxonomic groups. These predictions seem to be borne out but require closer scrutiny. Such traits are conversely predicted not to be similar to indicators of ill health. The good-genes and runaway-selection models make no prediction in this regard and in fact allow any trait to be selected (runaway selection) or allow any trait to be selected if it is condition dependent (good genes). Tests of the pathogen transmission avoidance hypothesis require some way of evaluating whether a trait exaggerates a normal sign of vigor. A very specific prediction is that strong female preferences should preexist and be functional even in nonshowy species. In contrast, in the good-genes and runaway-selection models, female preference must evolve along with the male trait and a preexistant preference cannot be explained. Although limited numbers of studies have looked for preexistent female preferences, several have found them. As discussed by Kirkpatrick and Ryan (1991), phylogenetic comparisons have identified preexisting 
strong preferences in frogs and xiphophorus fish. Similar results were found by Andersson (1982) for widow birds, in which females have a preference for a trait more exaggerated than any exhibited by males in the population. In addition, it is known that a number of mammals, including mice and livestock, reduce contact with sick conspecifics (see Loehle, 1995). In many flocking birds, individuals showing overt signs of disease are harrassed, pecked, and even driven from the flock. Thus some degree of disease detection and avoidance can be shown to be general and preexistent.

7. Risk from mating. A prediction of the pathogen transmission avoidance model is that mating poses a significant risk to female fitness via the mechanism of pathogen transmission. This prediction is much more subject to direct experimentation than is the heritability question, because it depends on positive evidence, though to date no data have been collected on the direct effects of female preferences on female survivorship or fecundity (Kirkpatrick and Ryan, 1991). The risk to females has two components: transmission rate and risk of consequences. The transmission rate for many diseases is easily determined on the basis of serologic assays of females allowed or not allowed to mate with males exhibiting various degrees of showiness. In an experimental setting, this risk may be underestimated, however, because most disease transmission (and selection) occurs during epidemics or during periods of adverse conditions (e.g., drought) when the males are sicker than usual and a higher proportion are sick. The estimation of the effect on female fitness may be a little more difficult. First, more than one pathogen may be transmitted at once, so the health effect observed may not necessarily result from the pathogen being studied experimentally. Second, the effect may be delayed. Most STDs exhibit a long delay between infection and illness, as observed in psittacine beak and feather disease and in human syphilis. The effects may also be indirect, as in sterility caused by brucellosis or in cervical cancer (in mammals) caused by viral infection. Finally, the major effect may be decreased vigor in the offspring, which would give the appearance of heritability of the brightness-fitness linkage, as discussed. 
Although female health and nutrition are widely known to affect offspring vigor, the effect with respect to particular pathogens will not be easy to quantify. Overall, the evidence suggests that most types of pathogens can be transmitted by mating. Although STDs (including yeasts, fungi, viruses, and bacteria) are obvious cases, they have been little studied in wildlife. Most of the well-studied diseases of wildlife, such as rabies, brucellosis, and myxomatosis, have been shown to be transmissible by mating. Clayton (1991) summarized a number of studies showing that direct life cycle ectoparasites can be transmitted by mating in a wide variety of species of birds and fish. These parasites can also act as transmission vectors for other pathogens. Only indirect life cycle parasites can be ruled out in this regard. Thus, evidence to date is that most diseases and ectoparasites can be transmitted by mating. What is not known is the incidence. It would be particularly instructive to partition mating versus nonmating risks for species living in large social groups and having nonshowy males compared to solitary, showy species.

8. Nontransmissible pathogens. Counter evidence to the pathogen transmission avoidance model would be provided by cases where the selection process is driven by nontransmissible pathogens. Such a case could only be explained by a good-genes model. Examples of nontransmissible pathogens include mosquitoes, biting flies, ticks, and indirect life cycle parasites (see Loehle, 1995, for classification). Because most species are also strongly affected by transmissible pathogens (in excreta or via body contact), it may be difficult to document a case where sexual selection has occurred solely under the influence of nontransmissible pathogens. Interestingly, Hausfater et al. (1990) documented a case, treefrogs, in which parasites are virtually all nontransmissible by mating. In this case, virtually no sexual selection effect occurred. Parasitism did not appear to affect male calling, and females were unable to discriminate between highly parasitized and weakly parasitized males. The authors noted that the strongest support for sexual selection theory has come from birds with blood protozoans that are probably directly transmissible during sexual encounters or are indirectly transmitted during mating by insect or ectoparasite vectors. This case in tree frogs is counter to a good genes model but is directly 
predicted by a pathogen transmission avoidance model since there is no risk of transmitting such pathogens during mating. More data of this type would be instructive.

9. Monogamy. Monogamy is predicted by the pathogen transmission avoidance model to decrease the strength of sexual selection pressures resulting from pathogen transmission. A simple epidemic model (Loehle, 1995) showed that monogamy can strongly inhibit STDs and other epidemics caused by body contact, as has also been shown in humans. The scant data available support this prediction. In a study of birds of paradise in Papua New Guinea, Pruett-Jones et al. (1990) found that the two monogamous species had lower rates of blood parasitism (46.9\% mean prevalence) than the eight promiscuous species ( $82.7 \%$ mean prevalence). The monogamous species were less showy and gave simpler calls than the promiscuous species, exactly as the pathogen transmission avoidance model predicts. Good genes models driven by differential male mating frequency for showy males also predict that polygynous (e.g., lekking) species should be the showiest. These models do not, however, explain the large number of showy (dimorphic) species among those that are largely solitary (see Appendix) and not polygynous, whereas the transmission avoidance model does (see point 1). In a provisioning model (as Price et al., 1993), females should choose bright males because they are more vigorous and will therefore be more helpful at the nest; implying that provisioning (nest-keeping by males) should increase brightness. However, the fact that monogamous species within a set of related species are duller than their promiscuous relatives in which the males do not provision, discussed above, is inconsistent with a provisioning model. Further, most males in colonial nesting species provision, but $95 \%$ of these species (N.A. birds) are not dimorphic (see point 1). The Fisher runaway process does not seem possible except in polygynous species, so these results for monogamous species can not be explained by runaway selection.

10. Direct detection of disease. If direct evidence of disease status is available, then showy traits should not evolve. An example occurs in species whose mating behavior is strongly 
dominated by scent. Many diseases produce changes in the smell of excreta. Skin diseases and parasites in the skin, fur, and feathers can affect animal odor. Mice (in the few cases studied) direct increased sniffing behaviors toward sick individuals and reduce physical contact with them. This observation might explain why so much more sexual selection is evident in birds, lizards, and fish compared to mammals, because their sense of smell is much reduced compared to their visual sense.

11. Taxonomic correlates. The prevalence (or absence) of showy traits within certain taxa requires explanation. A simple explanation involves the degree of sociality. A taxon that is predominantly highly social (with large social groups) should not exhibit showy traits, as discussed. For taxa where showiness is common, we run into difficulties within the good-genes and runaway-selection models. Both models have both a linkage threshold effect for the degree of linkage between female preference and showy traits and a frequency threshold effect for the initial unlikelihood that rare showy males and rare choosy females will encounter each other. Although founder effects and other mechanisms can be evoked to overcome these thresholds, it seems quite unlikely that a large number of species in one genus but not another would have overcome these thresholds, because each case involves a chance event. In addition, if in the root species female preference for a specific male trait evolves along with that trait, the wide divergence in displays between species within a taxonomic unit are difficult to explain. In contrast, the pathogen transmission avoidance model makes a specific prediction. If, in the root species of some taxonomic group, a strong general female trait evolves for choosiness with respect to signs of health, this change will foster a predisposition to favor novel males with showy traits that exaggerate signs of health. The particular male trait that becomes selected will be a matter of chance within individual species. A wide divergence in appearance will result between species within the group, but a high percentage of species in the group will exhibit showy traits. Thus, the pathogen transmission avoidance model makes a significant new prediction in this area. 
Preexistent female preference in root species has been demonstrated in at least a few cases (see point 6).

12. The handicap paradox. The pathogen transmission avoidance model overcomes a fundamental paradox of the handicap and good-genes models: that when the viability trait goes to fixation in the population, the female preference has no basis for operation (Clayton, 1990; Pomiankowski, 1988). If we assume that some type of handicap is operative (Zahavi, conditiondependent, or revealing), so that females choosing showier males obtain better genes for their offspring, then the choice differential relative to fitness is the result of the mix of male viability genotypes. As the viability genotype goes to fixation in the population, as it will in most such models (Pomiankowski, 1988), all males become equally good choices irrespective of showiness, and female choice loses its selective value. In this case, both female choosiness and male ornamentation will rapidly disappear, because both have costs (Pomiankowski, 1988). One must either assume very high deleterious mutation rates for viability (Hamilton, 1990) or cycling parasites, as in Hamilton and Zuk (1982) to maintain a selection differential. In Fisher's process, the preference and showiness traits will be extinguished if female choice has any cost (Pomiankowski, 1988), as is often the case. In the pathogen transmission avoidance model, by contrast, this paradox does not arise. This model is based on the prevalence of pathogens for which selection among existing genotypes is ineffective (i.e., for pathogens for which reducing transmission is more effective than is the evolution of defenses or immunity). Under these conditions, some males will always be healthier than others at any given time (and therefore less contagious), even if this trait is not heritable and even if particular males are not always the healthiest over time. A benefit of female choosiness will therefore always exist. Thus, no special assumptions are required to maintain showy traits. Female choosiness can have diminishing returns if choosiness reduces epidemic severity or frequency or selects for less virulent pathogens and thereby reduces the costs for nonchoosy females. This tendency along with the male and female costs of the show and choosiness, respectively, will tend to limit the sexual selection 
process below the most extreme level. In contrast, handicap and runaway-selection models will tend to go to fixation at extreme levels of showiness (Pomiankowski, 1988). In reality, most species exhibit modest male ornaments, in keeping with the pathogen transmission avoidance model.

\section{SUMMARY}

Overall, the pathogen transmission avoidance model makes a number of specific predictions. All of the predictions for which data exist seem to be supported, although data are sketchy at this time. Relatively simple experiments could test whether female avoidance of sick males is enhanced by showy traits, whether this avoidance decreases female risk, and whether showy males are actually more disease resistant.

I therefore conclude that the pathogen transmission avoidance theory of sexual selection has a number of advantages. It can be directly related to risks of pathogen transmission in various populations, and it makes a specific prediction that species living in large groups should not exhibit showy traits, because the traits do not reduce risk to the choosy female. The theory explains both the origin of the showy traits themselves, as exaggerated signs of good health, and the initial preference of females for showier males in terms of preexisting tendencies to avoid diseased individuals. The underlying model is operative when transmission risk is high, even in the absence of heritable variation for pathogen resistance traits, but it will lead to selection for resistance (or other good genes) traits if such variation is present. The model should be effective for both polygynous species and monogamous species, but it predicts that monogamous species will be less showy. A comparison with the good-genes and runaway-selection models (Table 1) shows that these two models leave many effects unexplained. Further, these two models both have serious difficulties initiating the sexual selection process. It is not being argued that selection via good genes and runaway processes do not occur, but rather that pathogen transmission avoidance may be far more common than the other two. The three models diverge on a number of 
points, and on each the pathogen transmission avoidance model seems both more parsimonious and more in accord with existing data. Overall, the model resolves difficulties with the good-genes and runaway-selection models and makes specific new predictions.

\section{ACKNOWLEDGMENTS}

This research is supported through contract W-31-109-ENG-38 by the U.S. Department of Energy, Office of Energy Research, Office of Health and Environmental Research, Program for Ecosystem Research. Helpful reviews provided by Jeffrey Gaffney, Kirk Lagory, Nancy Marley, and Steven Pruett-Jones. Editorial assistance provided by K. Haugen.

\section{DISCLAIMER}

This report was prepared as an account of work sponsored by an agency of the United States Government. Neither the United States Government nor any agency thereof, nor any of their empioyees, makes any warranty, express or implied, or assumes any legal liability or responsibility for the accuracy, completeness, or usefulness of any information, apparatus, product, or process disclosed, or represents that its use would not infringe privately owned rights. Reference herein to any specific commercial product, process, or service by trade name, trademark, manufacturer, or otherwise does not necessarily constitute or imply its endorsement, recommendation, or favoring by the United States Government or any agency thereof. The views and opinions of authors expressed herein do not necessarily state or reflect those of the United States Government or any agency thereof. 


\section{REFERENCES}

Andersson, M. 1982. Female choice selects for extreme tail length in widow birds. Nature 299:818-820.

Andersson, M. 1994. Sexual Selection. Princeton U. Press, Princeton, N.J.

Bakker, T. C. M. 1993. Positive genetic correlation between female preference and preferred male ornament in sticklebacks. Nature 363:255-257.

Barnard, P. 1991. Ornament and body size variation and their measurement in natural populations. Biological Journal of the Linnean Society 42:379-388.

Borgia, G., and K. Collis. 1989. Female choice for parasite-free male satin bowerbirds and the evolution of bright male plumage. Behavioral Ecology and Sociobiology 25:445-454.

Borgia, G., and K. Collis. 1990. Parasites and bright male plumage in the satin bowerbird Ptilonorhynchus violaceus. American Zoologist 30:279-285.

Catchpole, C. K. 1987. Bird song, sexual selection and female choice. Trends in Ecology and Evolution 2:94-97.

Clayton, D. H. 1990. Mate choice in experimentally parasitized rock doves: Lousy males lose. American Zoologist 30:251-262.

Clayton, D. H. 1991. The influence of parasites on host sexual selection. Parasitology Today 7:329-334. 
Edwards, J. C. 1988. The effects of Trichinella spiralis infection on social interactions in mixed groups of infected and uninfected male mice. Animal Behavior 36:529-540.

Edwards, J. C., and C. J. Barnard. 1987. The effects of Trichinella infection on intersexual interactions between mice. Animal Behavior 35:533-540.

Endler, J. A. 1980. Natural selection on color patterns in Poecilia reticulata. Evolution 34:76-91.

Fisher, R. A. 1958. The Genetical Theory of Natural Selection. 2nd Edn. Dover, New York.

Freeland, W. J. 1976. Pathogens and the evolution of primate sociality. Biotropica 8:12-24.

Grafen, A. 1990a. Sexual selection unhandicapped by the Fisher process. J. theoretical Biology $144: 473-516$.

Grafen, A. 1990b. Biological signals as handicaps. J. theoretical Biology 144:517-546.

Gibson, R. M. 1990. Relationships between blood parasites, mating success and phenotypic cues in male sage grouse Centrocercus urophasianus. American Zoologist 30:271-278.

Hamilton, W. D. 1990. Mate choice near or far. American Zoologist 30:341-352.

Hamilton, W. D., and M. Zuk. 1982. Heritable true fitness and bright birds: A role for parasites? Science 218:384-387.

Hart, B. L. 1987. Behavior of sick animals. Veterinary Clinics of North America: Food Animal Practice 2:383-391. 
Hart, B. L. 1990. Behavioral adaptation to pathogens and parasites: Five strategies. Neuroscience and Biobehavioral Reviews 14:273-294.

Hart, B. L., and C. M. Haugen. 1971. Prevention of genital grooming in mating behavior of male rats (Rattus norvegicus). Animal Behavior 19:230-232.

Hart, B. L., E. Korinek, and P. Brennan. 1987. Postcopulatory genital grooming in male rats: Prevention of sexually transmitted infections. Physiology and Behavior 41:321-325.

Hasson, O. 1989. Amplifiers and the handicap principal in sexual selection: A different emphasis. Proc. R. Soc. London B 235:383-406.

Hausfater, G., H. C. Gerhardt, and G. M. Klump. 1990. Parasites and mate choice in gray treefrogs, Hyla versicolor. American Zoologist 30:299-311.

Hill, G. E. 1990. Female house finches prefer colourful males: sexual selection for a conditiondependent trait. Animal Behaviour 40:563-572.

Hill, G. E. 1991. Plumage coloration is a sexually selected indicator of male quality. Nature 350:337-339.

Hill, G. E. 1995. Ornamental traits as indicators of environmental health. BioScience 45:25-31.

Houde, A. E. 1987. Mate choice based upon naturally occurring color-pattern variation in a guppy population. Evolution 41:1-10.

Hoelzer, G. A. 1989. The good parent process of sexual selection. Animal Behaviour 38:10671078. 
Houde, A. E., and J. A. Endler. 1990. Correlated evolution of female mating preferences and male color patterns in the guppy Poecilia reticulata. Science 248:1405-1408.

Kennedy, C. E. J., A. Endler, S. L. Poynton, and H. McMinn. 1987. Parasite load predicts mate choice in guppies. Behavioral Ecology and Sociobiology 21:291-295.

Kirkpatrick, M. 1986. Sexual selection and cycling parasites: A simulation study of Hamilton's hypothesis. Journal of Theoretical Biology 119:263-271.

Kirkpatrick, M. 1989. Sexual selection: Is bigger always better? Nature 337:116-117.

Kirkpatrick, M., and M. J. Ryan. 1991. The evolution of mating preferences and the paradox of the lek. Nature 350:33-38.

Lande, R. 1981. Models of speciation by sexual selection on polygenic characters. Proceedings, National Academy of Science, USA, 78:3721-3725.

Loehle, C. 1995. Social barriers to pathogen transmission in wild animal populations. Ecology 76:326-335.

Lyon, B. E. and R. D. Montgomerie. 1986. Delayed plumage maturation in passerine birds: reliable signalling by subordinate males? Evolution 40:605-615.

M6ller, A. P. 1991b. Sexual selelction in the monogamous barn swallow (Hirundo rustica). I. Determinants of tail ornament size. Evolution 45:1823-1836.

Nichols, R. A., and R. K. Butlin. 1989. Does runaway sexual selection work in finite populations? J. Evolutionary Biology 2:299-313. 
Pomiankowski, A. N. 1988. The evolution of female mate preferences for male genetic quality. Oxford Surveys in Evolutionary Biology 5:136-184

Price, T., D. Schluter, and N. E. Heckman. 1993. Sexual selection when the female directly benefits. Biological J. Linnean Society 48:187-211.

Pruett-Jones, S. G., M. A. Pruett-Jones, and H. I. Jones. 1990. Parasites and sexual selection in birds of paradise. American Zoologist 30:287-298.

Rätti, O., R. Dufva, and R. V. Alatalo. 1993. Blood parasites and male fitness in the pied flycatcher. Oecologia 96:410-414.

Read, A. F. 1988. Sexual selection and the role of parasites. Trends in Ecology and Evolution 3:97-102.

Read, A. F., and P. H. Harvey. 1989. Reassessment of comparative evidence for Hamilton and Zuk theory on the evolution of secondary sexual characters. Nature 339:618-620.

Reznick, D. A., H. Bryga, and J. A. Endler. 1990. Experimentally induced life-history evolution in a natural population. Nature 346:356-359.

Robbins, C. S., B. Braun, and H. S. Zim. 1983. Birds of North America. Golden Press, NY.

Searcy, W. A. and M. Andersson. 1986. Sexual selection and the evolution of song. Annual Review of Ecology and Systematics 17:507-533.

Service, M. W. 1986. Blood-Sucking Insects: Vectors of Disease. Edward Arnold, London. 
Simmons, R. 1988. Honest advertisting, sexual slection, courtship displays, and body condition of polygynous male harriers. Auk 105:303-307.

Terres, J. K. 1980. The Audubon Society Encyclopedia of North American Birds. Alfred A. Knopf, NY.

von Schantz, T., M. Grahn, and G. Göransson. 1994. Intersexual selection and reproductive success in the pheasant Phasianus colchicus. American Naturalist 144:510-527.

Witter, J. F. 1981. Brucellosis, pages 280-287, in Davis, J. W., L. H. Karstad, and D. O. Trainer, D. O. (eds.). Infectious Diseases of Wild Animals. Iowa State University Press, Ames.

Yuill, T. M. 1981. Myxomatosis and fibromatosis, pages 154-177, in Davis, J. W., L. H. Karstad, and D. O. Trainer (eds.). Infectious Diseases of Wild Animals. Iowa State University Press, Ames.

Zahavi, A. 1975. Mate selection - a selection for a handicap. J. theoretical Biology 53:205-214.

Zahavi, A. 1987. The theory of signal selection and some of its implications. In: International Symposium of Biological Evolution. (V. P. Delfino, ed.). Adriatica Editrice, Bari. 
Table 1. Comparison of three main theories of sexual selection

Predictions of Models

\begin{tabular}{|c|c|c|c|c|}
\hline & & & & \multirow[b]{2}{*}{$\begin{array}{c}\text { Actual } \\
\text { Data }\end{array}$} \\
\hline & $\begin{array}{l}\text { Pathogen } \\
\text { Avoidance }\end{array}$ & $\begin{array}{l}\text { Good } \\
\text { Genes }\end{array}$ & $\begin{array}{l}\text { Runaway } \\
\text { Selection }\end{array}$ & \\
\hline Benefit of traits & $\begin{array}{l}\text { Increased female } \\
\text { fecundity }\end{array}$ & $\begin{array}{l}\text { Increased offspring } \\
\text { fitness }\end{array}$ & $\begin{array}{l}\text { None, maybe net } \\
\text { population detriment }\end{array}$ & $\begin{array}{l}\text { Experiments } \\
\text { ambiguous }\end{array}$ \\
\hline $\begin{array}{l}\text { Relation to group } \\
\text { size }\end{array}$ & $\begin{array}{l}\text { Few secondary sex } \\
\text { traits in species } \\
\text { living in large groups }\end{array}$ & $\begin{array}{l}\text { Largest groups } \\
\text { showiest? }\end{array}$ & $\begin{array}{l}\text { Random w/re group } \\
\text { size }\end{array}$ & $\begin{array}{l}95 \% \text { colonial nesting } \\
\text { species not dimorphic. } \\
\text { Solitary species most } \\
\text { dimorphic }\end{array}$ \\
\hline $\begin{array}{l}\text { Showiness versus } \\
\text { parasitism level }\end{array}$ & $\begin{array}{l}\text { Showiest species } \\
\text { most parasitized; data } \\
\text { should be ambiguous }\end{array}$ & $\begin{array}{l}\text { Showiest species } \\
\text { most parasitized } \\
\text { (assuming cycling } \\
\text { parasites) }\end{array}$ & $\begin{array}{l}\text { Showiest species } \\
\text { most parasitized } \\
\text { because of energetic } \\
\text { cost of display }\end{array}$ & $\begin{array}{l}\text { Show iest species } \\
\text { most parasitized (data } \\
\text { limited and ambiguous); }\end{array}$ \\
\hline $\begin{array}{l}\text { Genetic linkage } \\
\text { threshold }\end{array}$ & None & Yes & Yes & $\begin{array}{l}\text { Linkage not } \\
\text { demonstrated }\end{array}$ \\
\hline Frequency threshold & None & Yes & Yes & $\begin{array}{l}\text { No studies of } \\
\text { frequency effect }\end{array}$ \\
\hline $\begin{array}{l}\text { Origin of female } \\
\text { choosiness }\end{array}$ & $\begin{array}{l}\text { Based on general signs } \\
\text { of health, preexistent }\end{array}$ & $\begin{array}{l}\text { Unexplained, } \\
\text { arbitrary, not } \\
\text { preexistent }\end{array}$ & $\begin{array}{l}\text { Unexplained, } \\
\text { arbitrary, not } \\
\text { preexistent }\end{array}$ & $\begin{array}{l}\text { Preexistent strong } \\
\text { preference observed } \\
\text { in several taxa }\end{array}$ \\
\hline Origin of male trait & $\begin{array}{l}\text { Exaggeration of } \\
\text { signs of vigor }\end{array}$ & $\begin{array}{l}\text { Unexplained, } \\
\text { arbitrary }\end{array}$ & $\begin{array}{l}\text { Unexplained, } \\
\text { arbitrary }\end{array}$ & No tests conducted \\
\hline $\begin{array}{l}\text { Variation in traits } \\
\text { between related } \\
\text { species }\end{array}$ & $\begin{array}{l}\text { Chance origin of } \\
\text { exaggerated vigor } \\
\text { trait gives high } \\
\text { variation }\end{array}$ & $\begin{array}{l}\text { Appears to require } \\
\text { diverging female } \\
\text { choice trait }\end{array}$ & $\begin{array}{l}\text { Unexplained, } \\
\text { arbitrary }\end{array}$ & $\begin{array}{l}\text { High } \\
\text { variation }\end{array}$ \\
\hline $\begin{array}{l}\text { Frequency of } \\
\text { showiness within } \\
\text { taxonomic group }\end{array}$ & $\begin{array}{l}\text { High consistency } \\
\text { within group due } \\
\text { to strong selection for } \\
\text { fermale preference for } \\
\text { signs of vigor in } \\
\text { root species }\end{array}$ & $\begin{array}{l}\text { Unexplained, } \\
\text { unlikely due to } \\
\text { threshold } \\
\text { effects }\end{array}$ & $\begin{array}{l}\text { Unexplained, } \\
\text { unlikely due to } \\
\text { threshold } \\
\text { effects }\end{array}$ & $\begin{array}{l}\text { High consistency } \\
\text { within taxonomic } \\
\text { groups (see appendix) }\end{array}$ \\
\hline $\begin{array}{l}\text { Effectiveness } \\
\text { against different } \\
\text { pathogens }\end{array}$ & $\begin{array}{l}\text { Effective against } \\
\text { transmissible types } \\
\text { only }\end{array}$ & $\begin{array}{l}\text { Effective in theory } \\
\text { against all types }\end{array}$ & Not effective & $\begin{array}{l}\text { Data on female } \\
\text { preference positive } \\
\text { for transmissible, } \\
\text { negative for } \\
\text { nontransmissible }\end{array}$ \\
\hline $\begin{array}{l}\text { Heritability of } \\
\text { pathogen resistance } \\
\text { or fitness in showy } \\
\text { males' offspring }\end{array}$ & Variable & High & None & $\begin{array}{l}\text { Experiments } \\
\text { ambiguous; could } \\
\text { support variable } \\
\text { heritability }\end{array}$ \\
\hline $\begin{array}{l}\text { Risk to female } \\
\text { fitness due } \\
\text { to mating }\end{array}$ & $\begin{array}{l}\text { High in solitary or } \\
\text { small-group species, } \\
\text { low in large groups }\end{array}$ & Not considered & Not considered & $\begin{array}{l}\text { Qualitative data show } \\
\text { risk exists }\end{array}$ \\
\hline Effect of monogamy & $\begin{array}{l}\text { Reduced parasitism } \\
\text { rate, reduced male } \\
\text { showiness }\end{array}$ & $\begin{array}{l}\text { Maybe reduced } \\
\text { male showiness, } \\
\text { no prediction of } \\
\text { reduced parasitism }\end{array}$ & $\begin{array}{l}\text { Can't operate under } \\
\text { monogamy }\end{array}$ & $\begin{array}{l}\text { Reduced parasitism, } \\
\text { reduced male } \\
\text { showiness }\end{array}$ \\
\hline $\begin{array}{l}\text { Maintenance of traits } \\
\text { once established }\end{array}$ & $\begin{array}{l}\text { Showiness provides } \\
\text { continued benefit by } \\
\text { reducing transmission }\end{array}$ & $\begin{array}{l}\text { Requires continued } \\
\text { viability variance by } \\
\text { cycling parasites etc. }\end{array}$ & $\begin{array}{l}\text { Ornaments and } \\
\text { choosiness eliminated } \\
\text { if any cost to female } \\
\text { choice }\end{array}$ & $\begin{array}{l}\text { No evidence for } \\
\text { cycling parasites }\end{array}$ \\
\hline
\end{tabular}


Table 2. Contingency table analysis of dimorphism versus social behaviors $\left(\chi^{2}=131.2\right.$ versus $\left.\chi_{.99}^{2}(2)=10.6\right)$.

\begin{tabular}{l|cc|c}
\multirow{2}{*}{ Social } & \multicolumn{2}{|c}{ Sexual Dimorphism } \\
\multicolumn{1}{c|}{ Behavior } & Dimorphic & Not & Total \\
\hline Colonial nesting & 7 & 137 & 142 \\
Gregarious & 76 & 124 & 200 \\
Solitary & 199 & 102 & 301 \\
Total & 282 & 362 & 645
\end{tabular}


Appendix I.

Classification of North American bird species by sexual dimorphism and social habits.

Dimorphism

Loons

Grebes

Tubenoses

Pelicans

Frigatebird + anhinga

Swans + geese

Raptors

Gallinaceous

Herons

Bitterns

Stork-like

Cranes

Rails

Shorebirds

Sandpipers

Ducks

Eider ducks

Phalaropes

Woodcock + snipe

Jaegers + skuas

Gulls

Terns

Alcids

Pigeons

(inc. passenger)

Cuckoos

Owls

Goatsuckers

Swifts

Hummingbirds
Dimorphic

Not

Not

Not

Dimorphic

Not

Dimorphic (by size)

Dimorphic

Not

Not

Not

Not

Not

Not

Not

Dimorphic

Dimorphic

Not

Dimorphic

Dimorphic

Not

Not

Not

Not

Not

Not

Not

Not

Dimorphic (by size)

Dimorphic

Not

Not

Dimorphic
Sociality

Solitary

Solitary

Colonial nesting

Colonial nesting

Colonial nesting

Gregarious

Solitary

Gregarious

Colonial nesting

Solitary

Colonial nesting

Colonial nesting

Gregarious

Gregarious

Gregarious

Gregarious

Solitary

Gregarious

Colonial nesting

Solitary

Solitary

Colonial nesting

Colonial nesting

Colonial nesting

Colonial nesting

Colonial nesting

Gregarious

Solitary

Solitary

Solitary

Solitary

Colonial nesting

Solitary
Number Species

4 6

23

15

2

13

34

22

11

2

6

2

9

6

34

16

15

1

4

3

2

5

23

17

19

3 


\begin{tabular}{|c|c|c|c|}
\hline Trogons & Dimorphic & Solitary & 1 \\
\hline Kingfishers & Dimorphic & Solitary & 3 \\
\hline \multirow[t]{3}{*}{ Woodpeckers } & Dimorphic & Solitary & 11 \\
\hline & Not & Solitary & 2 \\
\hline & Not & Gregarious & 2 \\
\hline \multirow[t]{2}{*}{ Flycatchers } & Not & Solitary & 28 \\
\hline & Dimorphic & Solitary & 5 \\
\hline Larks & Not & Gregarious & 1 \\
\hline \multirow[t]{2}{*}{ Swallows } & Not & Colonial nesting & 7 \\
\hline & Dimorphic & Colonial nesting & 1 \\
\hline Jays, magpies + crows & Not & Gregarious & 16 \\
\hline Chickadees & Not & Gregarious & 7 \\
\hline Titmice & Not & Gregarious & 3 \\
\hline Bushtit & Dimorphic & Gregarious & 1 \\
\hline Wrentit & Not & Solitary & 1 \\
\hline Bulbul & Not & Gregarious & 1 \\
\hline Dipper & Not & Solitary & 1 \\
\hline \multirow[t]{2}{*}{ Nuthatches } & Not & Gregarious & 2 \\
\hline & Dimorphic & Gregarious & 2 \\
\hline Creeper & Not & Solitary & 1 \\
\hline Wrens & Not & Solitary & 9 \\
\hline $\begin{array}{l}\text { Mockingbirds + } \\
\text { thrashers }\end{array}$ & Not & Solitary & 10 \\
\hline Thrushes, solitaires & Not & Gregarious & 8 \\
\hline + bluebirds & Dimorphic & Gregarious & 13 \\
\hline Wagtails + pipits & Not & Solitary & 9 \\
\hline Waxwings & Not & Gregarious & 2 \\
\hline Silky flycatchers & Dimorphic & Gregarious & 1 \\
\hline Shrikes & Not & Solitary & 2 \\
\hline Starlings & Not & Gregarious & 2 \\
\hline \multirow[t]{2}{*}{ Vireos } & Dimorphic & Solitary & 1 \\
\hline & Not & Solitary & 11 \\
\hline \multirow[t]{2}{*}{ Wood-warblers } & Not & Solitary & 9 \\
\hline & Dimorphic & Solitary & 44 \\
\hline Sparrow & Dimorphic & Solitary & 1 \\
\hline \multirow[t]{3}{*}{ Blackbirds + orioles } & Dimorphic & Solitary & 12 \\
\hline & Dimorphic & Gregarious & 4 \\
\hline & Not & Gregarious & 5 \\
\hline Tanagers & Dimorphic & Solitary & 5 \\
\hline Grosbeaks, buntings & Dimorphic & Solitary & 10 \\
\hline
\end{tabular}




\begin{tabular}{lllr} 
Finches & Dimorphic & Solitary & 5 \\
Goldfinches & Dimorphic & Gregarious & 4 \\
Crossbills & Dimorphic & Solitary & 4 \\
Towhee & Not & Solitary & 3 \\
& Dimorphic & Solitary & 1 \\
Sparrows & Not & Gregarious & 24 \\
& Dimorphic & Gregarious & 7 \\
Juncos & Dimorphic & Gregarious & 1 \\
& Not & Gregarious & 1 \\
Longspurs + buntings & Dimorphic & Gregarious & 6 \\
\hline
\end{tabular}




\section{Figure Legends}

Figure 1. Elimination of nonchoosy females in a disease transmission model. Note that as pathogen incidence is reduced, selection against nonchoosy females ceases.

Figure 2. Population pathogen (epidemic) risk as a function of degree of choosiness of females and brightness of males. Choosy females are assumed to be able to detect sick males to some degree even in the absence of showy male traits.

Figure 3. Selection strength (arrow length) and direction (arrow direction) for choosiness and showiness in a population. When showy traits are pronounced, females do not require even showier traits to avoid diseased males, so the process is self-limiting. It is also self-limiting as the showy traits act to reduce disease transmission and thus risk (selection pressure).

Figure 4. Sexual dimorphism versus degree of sociality for North American birds, showing the predicted trend of colonial nesting species to be least dimorphic. 


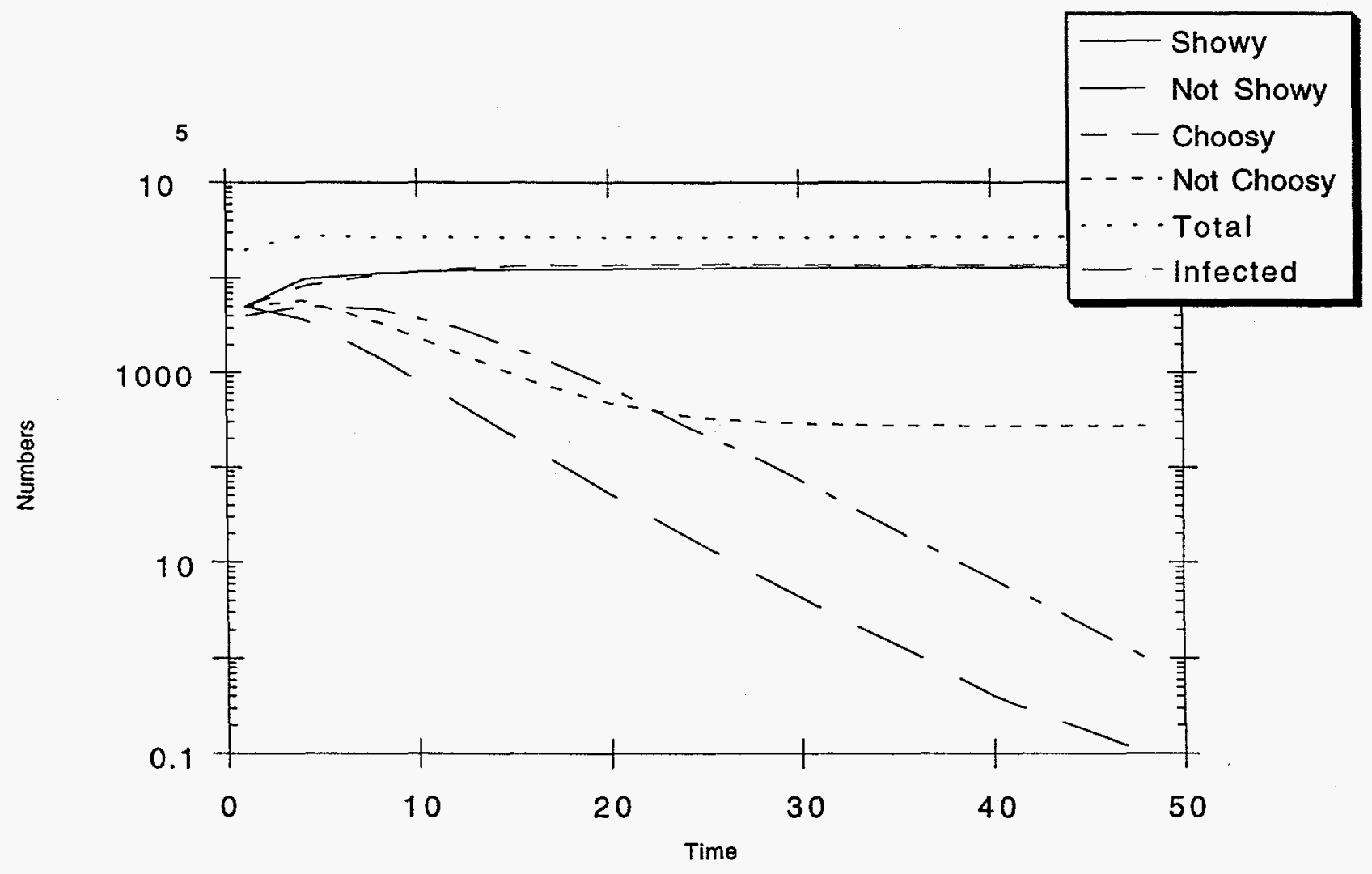

Fig. 1 


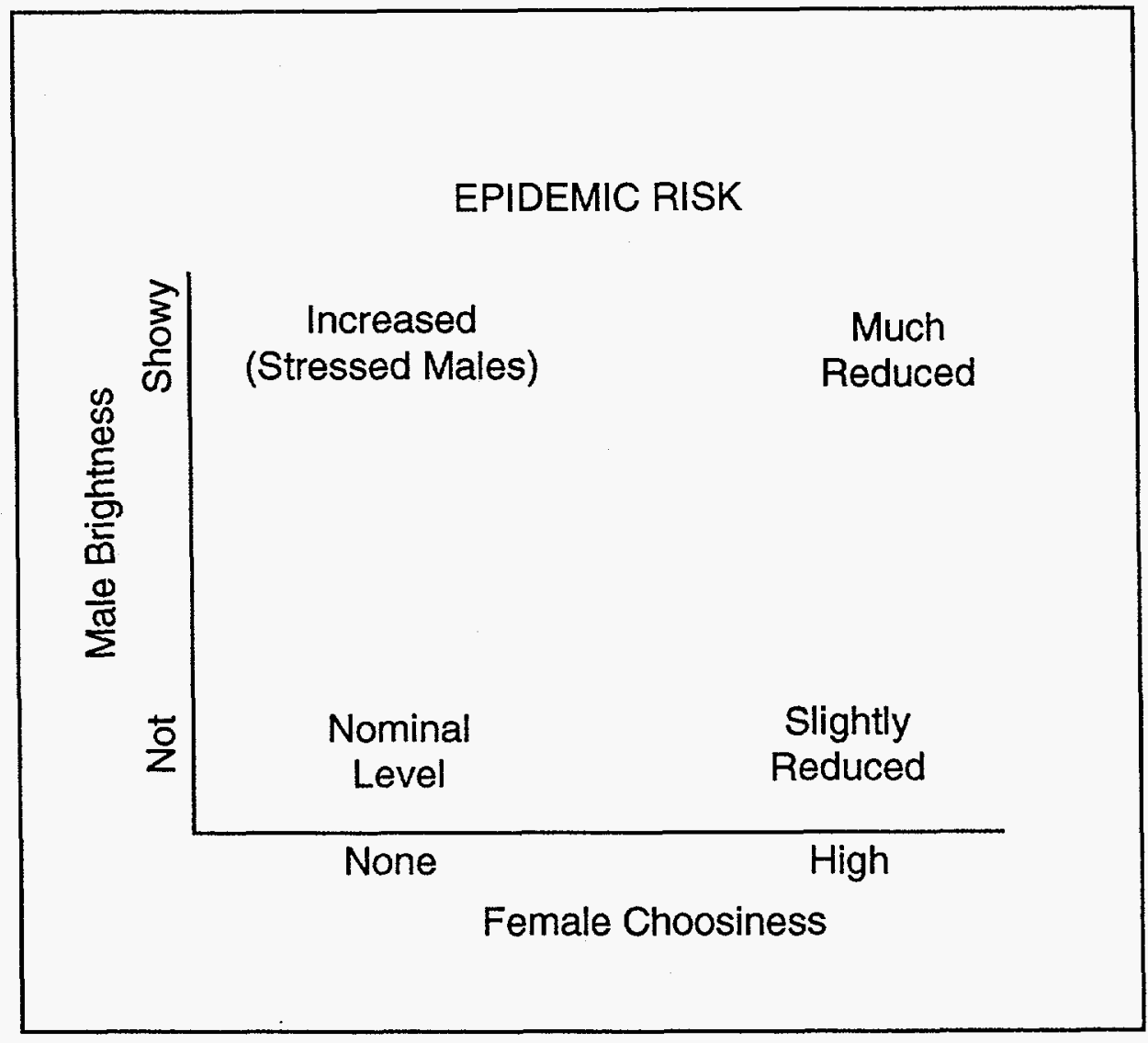

Fig. 2 


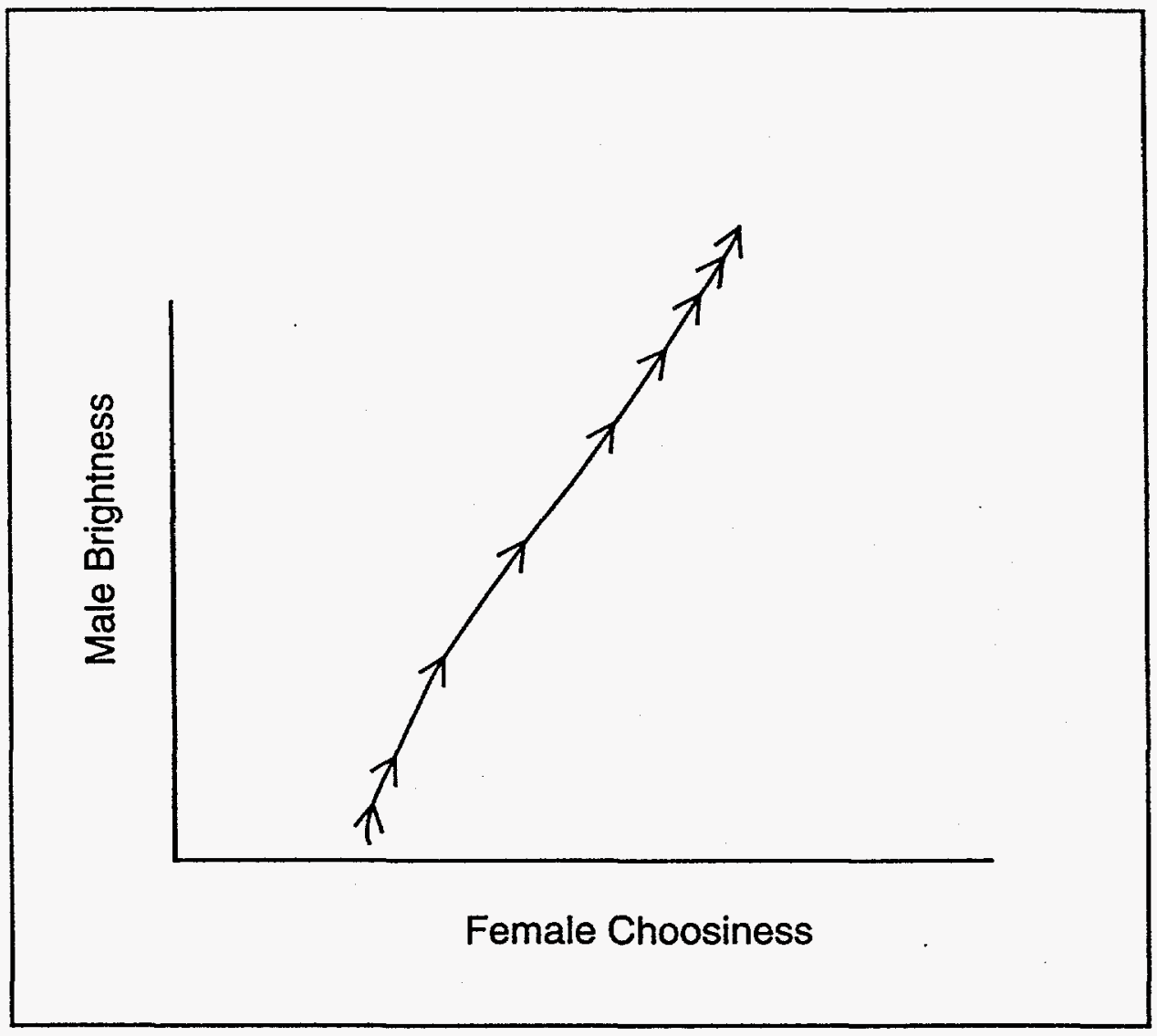

Fig. 3 
- Not dimorphic

Dimorphic

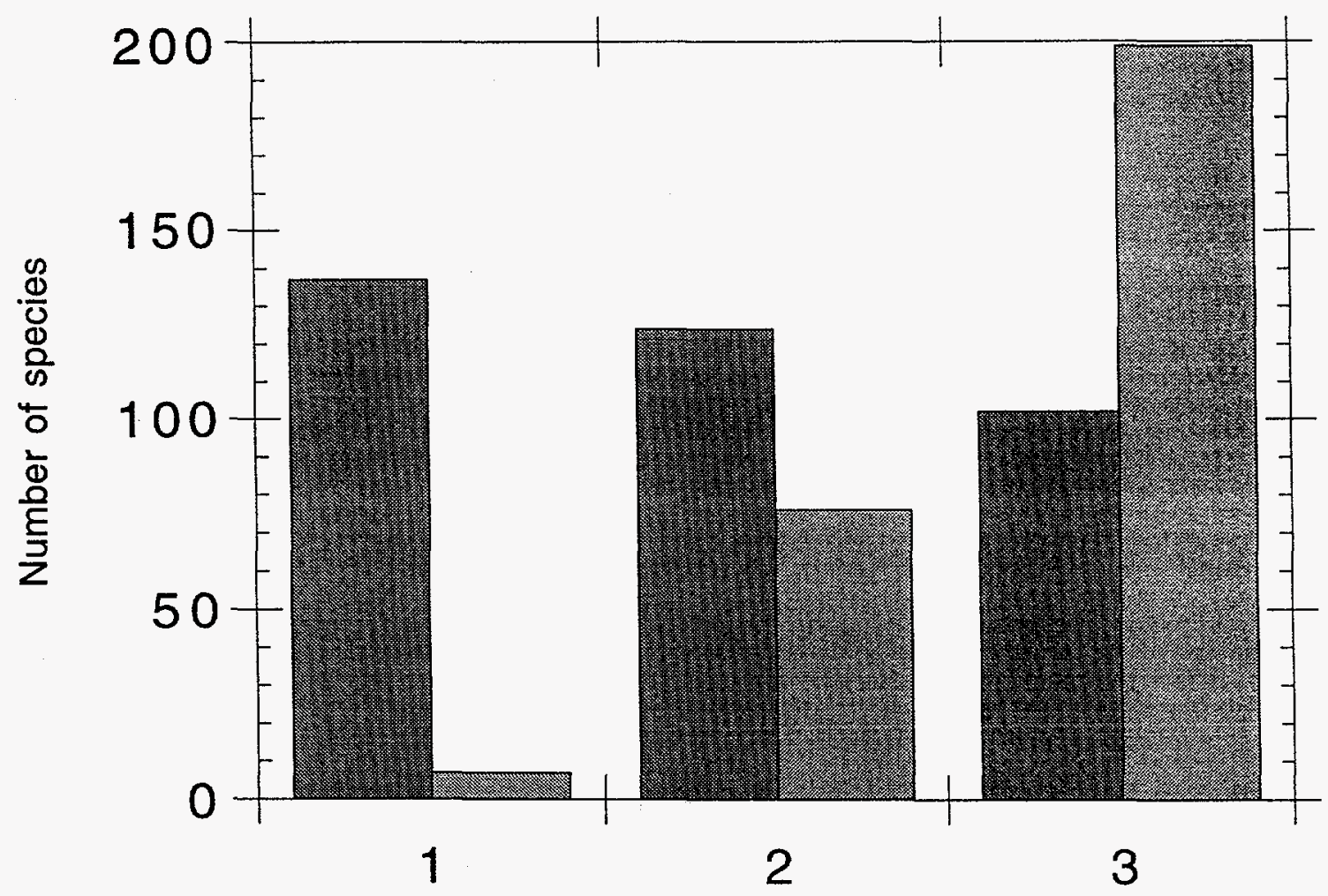

Sociality ( $1=$ colonial nesting, $2=$ gregarious, $3=$ solitary)

Fig. 4 